\title{
Phosphorus and nitrogen losses in relation to forest, pasture and row-crop land use and precipitation distribution in the midwest usa
}

\section{Pertes en phosphore et azote selon l'occupation des sols (forêt, pâturage, cultures à interlignes) et la précipitation dans le Midwest des États-Unis d'Amérique}

\author{
Ranjith P. Udawatta, Gray S. Henderson, John R. Jones et David Hammer
}

Volume 24, numéro 3, 2011

Reçu le 15 avril 2009, accepté le 7 octobre 2010

URI : https://id.erudit.org/iderudit/1006477ar

DOI : https://doi.org/10.7202/1006477ar

Aller au sommaire du numéro

Éditeur(s)

Université du Québec - INRS-Eau, Terre et Environnement (INRS-ETE)

ISSN

1718-8598 (numérique)

Découvrir la revue

Citer cet article

Udawatta, R. P., Henderson, G. S., Jones, J. R. \& Hammer, D. (2011). Phosphorus and nitrogen losses in relation to forest, pasture and row-crop land use and precipitation distribution in the midwest usa. Revue des sciences de l'eau / Journal of Water Science, 24(3), 269-281. https://doi.org/10.7202/1006477ar

\section{Résumé de l'article}

Il y a peu d'information disponible sur les liens entre l'occupation des sols, la précipitation et le contrôle des pertes en phosphore (P) et en azote (N) des bassins versants ayant des sols aux horizons argileux. Pour cette étude, huit bassins caractérisés par différentes proportions de culture à interlignes, pâturage, forêt et conditions de bandes enherbées, ont été suivis sur une période de trois ans. Les pertes en $\mathrm{P}$ total (TP) et $\mathrm{N}$ total (TN) étaient inversement reliées au pourcentage d'occupation en forêt et en pâturage. Les occupations forêt ( $(n=2)$, pâturage $(n=3)$, cultures à interligne sans $(n=2)$ et avec bandes enherbées $(\mathrm{n}=1)$, avaient respectivement des pertes annuelles moyennes de TP de 0,43, 0,90, 3,82, et 1,30 kg.ha- ${ }^{1}$ •année- ${ }^{1}$ et de TN de 2,02,

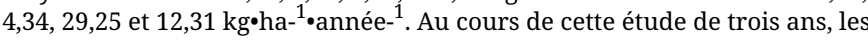
pertes en azote nitrate étaient respectivement de $0,36,0,64,13,99$, et $7,26 \mathrm{~kg} \mathrm{~N}-\mathrm{NO}_{3} \cdot$ ha- $^{1} \cdot$ année- ${ }^{1}$. Les pertes résultant des événements de ruissellement sur les bassins de cultures à interlignes étaient plus considérables que celles sur les bassins caractérisés par la forêt et les pâturages. Les concentrations en azote nitrate dans les cours d'eau alimentés par les occupations forêt, pâturage et cultures à interlignes étaient respectivement de $0,39,0,50$, et $2,56 \mathrm{mg} \mathrm{N}-\mathrm{NO}_{3} \cdot \mathrm{L}^{-}{ }^{1}$. Au cours de l'étude, et ce en comparaison avec les années ayant reçu des précipitations inférieures à la moyenne à long terme, les précipitations de 1998 (136\% de la moyenne à long terme) ont produit plus de pertes dans tous les types de bassins ainsi que de plus grandes variabilités pour chaque occupation. Les résultats de cette étude illustrent que l'intégration de couvertures végétales pérennes, telles que les bandes enherbées, les aires protégées enherbées et les voies enherbées ou autre végétation pérenne, représente une option à long terme pour le contrôle efficace des pertes en nutriments par ruissellement dans les bassins agricoles.
Ce document est protégé par la loi sur le droit d'auteur. L’utilisation des services d’Érudit (y compris la reproduction) est assujettie à sa politique d'utilisation que vous pouvez consulter en ligne.

https://apropos.erudit.org/fr/usagers/politique-dutilisation/ 


\title{
PHOSPHORUS AND NITROGEN LOSSES IN RELATION TO FOREST, PASTURE AND ROW-CROP LAND USE AND PRECIPITATION DISTRIBUTION IN THE MIDWEST USA
}

\author{
Pertes en phosphore et azote selon l'occupation des sols (forêt, pâturage, cultures à interlignes) \\ et la précipitation dans le Midwest des Etats-Unis d'Amérique
}

RANJITH P. UDAWATTA ${ }^{1,2 *}$, GRAY S. HENDERSON ${ }^{3}$, JOHN R. JONES ${ }^{4}$ AND DAVID HAMMER

${ }^{1}$ Department of Soil, Environmental and Atmospheric Sciences, University of Missouri, Colombia, MO, USA

${ }^{2}$ Center for Agroforestry, University of Missouri, Colombia, MO, USA

${ }^{3}$ Department of Forestry, University of Missouri, Colombia, MO, USA

${ }^{4}$ Department of Fisheries and Wildlife, University of Missouri, Colombia, MO, USA

${ }^{5}$ National Soil Survey Center, Centennial Mall, Lincoln, NE, USA

Reçu le 15 avril 2009, accepté le 7 octobre 2010

\section{ABSTRACT}

Little information is available comparing the influence of land use and precipitation on the control of phosphorus (P) and nitrogen $(\mathrm{N})$ losses from agricultural watersheds in claypan soils. Eight watersheds with varying proportions of row-crop, pasture, forest, and grass filter strip condition were examined for three consecutive years to evaluate effects of land use and precipitation on $\mathrm{P}$ and $\mathrm{N}$ losses from row-cropped watersheds. Total $\mathrm{P}(\mathrm{TP})$ and total $\mathrm{N}$ (TN) losses were inversely related to the percentage of forest and pasture cover. Forest $(n=2)$, pasture $(n=3)$, row-crop $(n=2)$, and row-crop grass filter strip $(\mathrm{n}=1)$ land use types had mean annual TP losses of $0.43,0.90,3.82$ and $1.30 \mathrm{~kg}^{\bullet} \mathrm{ha}^{-1} \bullet \mathrm{yr}^{-1}$, respectively and mean annual TN losses of 2.02, 4.34, 29.25 and $12.31 \mathrm{~kg} \bullet \mathrm{ha}^{-1} \bullet \mathrm{yr}^{-1}$, respectively. During the 3-year study, the respective land use types lost $0.36,0.64,13.99$ and $7.26 \mathrm{~kg} \mathrm{NO}{ }_{3}^{-} \mathrm{N} \cdot \mathrm{ha}^{-1} \cdot \mathrm{yr}^{-1}$. Runoff events on row-cropped watersheds resulted in significantly greater TP, TN, and $\mathrm{NO}_{3}{ }^{-} \mathrm{N}$ losses than those from pastured and forested watersheds. Stream nitrate- $\mathrm{N}$ concentrations averaged $0.39,0.50$, and
$2.56 \mathrm{mg} \bullet \mathrm{L}^{-1}$ for forest, pasture, and row-crop land use types, respectively. During the study, $136 \%$ of the long-term average precipitation in 1998 caused significant nutrient losses in all watershed categories and the variability within a land use type was larger than in years with below long-term rainfall. The study results emphasize the incorporation of perennial vegetation such as vegetative buffers, grass/conservation reserve program areas, and grass filter strips or other perennial vegetation as a long-term option for effective control of nutrient losses in runoff from agricultural watersheds.

\section{Keywords: buffers, corn-soybean, conservation practices, grass filter strips, riparian area}

\section{RÉSUMÉ}

Il y a peu d'information disponible sur les liens entre l'occupation des sols, la précipitation et le contrôle des pertes en phosphore $(\mathrm{P})$ et en azote $(\mathrm{N})$ des bassins versants ayant

*Auteur pour correspondance:

Téléphone: 573-882-4347

T.élécopieur: 573-882-1977

Courriel : udawattar@missouri.edu 
des sols aux horizons argileux. Pour cette étude, huit bassins caractérisés par différentes proportions de culture à interlignes, pâturage, forêt et conditions de bandes enherbées, ont été suivis sur une période de trois ans. Les pertes en P total (TP) et $\mathrm{N}$ total (TN) étaient inversement reliées au pourcentage d'occupation en forêt et en pâturage. Les occupations forêt $(n=2)$, pâturage $(n=3)$, cultures à interligne sans $(n=2)$ et avec bandes enherbées $(\mathrm{n}=1)$, avaient respectivement des pertes annuelles moyennes de TP de 0,43, 0,90, 3,82, et $1,30 \mathrm{~kg} \bullet \mathrm{ha}^{-1} \bullet$ année $^{-1}$ et de TN de 2,02, 4,34, 29,25 et $12,31 \mathrm{~kg} \bullet \mathrm{ha}^{-1} \bullet$ année $^{-1}$. Au cours de cette étude de trois ans, les pertes en azote nitrate étaient respectivement de 0,36, 0,64, 13,99 , et $7,26 \mathrm{~kg} \mathrm{~N}-\mathrm{NO}_{3} \bullet \mathrm{ha}^{-1} \bullet$ année $^{-1}$. Les pertes résultant des événements de ruissellement sur les bassins de cultures à interlignes étaient plus considérables que celles sur les bassins caractérisés par la forêt et les pâturages. Les concentrations en azote nitrate dans les cours d'eau alimentés par les occupations forêt, pâturage et cultures à interlignes étaient respectivement de $0,39,0,50$, et $2,56 \mathrm{mg} \mathrm{N}-\mathrm{NO}_{3} \bullet \mathrm{L}^{-1}$. Au cours de l'étude, et ce en comparaison avec les années ayant reçu des précipitations inférieures à la moyenne à long terme, les précipitations de 1998 (136\% de la moyenne à long terme) ont produit plus de pertes dans tous les types de bassins ainsi que de plus grandes variabilités pour chaque occupation. Les résultats de cette étude illustrent que l'intégration de couvertures végétales pérennes, telles que les bandes enherbées, les aires protégées enherbées et les voies enherbées ou autre végétation pérenne, représente une option à long terme pour le contrôle efficace des pertes en nutriments par ruissellement dans les bassins agricoles.

\section{Mots-clés : zones tampons, mä̈s-soya, pratiques de protection, bandes enherbées, zones riveraines.}

\section{INTRODUCTION}

Despite improvements in fertilizer application, crop rotation, and use of conservation practices, row-crop watersheds still lose nutrients causing significant impacts on water quality (UDAWATTA et al., 2006a). In the Midwestern United States, the agriculture sector has been recognized as the single largest contributor to non-point source nitrate $\left(\mathrm{NO}_{3}^{-}\right)$pollution of surface and ground waters (HATFIELD et al., 1999; JAYNES et al., 1999; TOMER and BURKART, 2003). OMERNIK (1977) observed that total nitrogen (TN) concentrations in streams were nearly nine times greater from agricultural lands than from forests, with the highest concentrations found in the corn-belt states. There are strong correlations between watershed land use and stream nutrient concentrations (COULTER et al., 2004; KANG et al., 2008; SCHILLING and SPOONER, 2006; UDAWATTA et al., 2006b). Among the land use parameters, percentages of agricultural and forest areas have been shown to explain significant variation in stream nutrient concentrations (JONES et al., 2001; PERKINS et al., 1998; SCHILLING and SPOONER, 2006).

Perennial vegetation has received increasing attention as a way to reduce nutrient losses from agricultural watersheds. For example, riparian buffer zones, grass filter strips, and pasture areas, positioned between the agricultural land and aquatic environment, have been shown to remove excess nutrients (PETERJOHN and CORRELL, 1984; PUCKETT, 2004; SCHMITT et al., 1999; WIGINGTON et al., 2003). Sediment, organic matter, nutrients, and agrichemicals from surface and subsurface water are removed by vegetation uptake, diffusing surface flow, increasing infiltration, and trapping sediment (MCINTYRE, 1993; PARSONS et al., 1994; PETERJOHN and CORRELL, 1984; UDAWATTA et al., 2002; WELSCH, 1992; WIGINGTON et al., 2003). The uptake of nitrogen through riparian forests has been documented by several studies with removal efficiencies greater than 80\% (GILLIAM, 1994; JACOBS and GILLIAM, 1985; LOWRANCE et al., 1984; PETERJOHN and CORRELL, 1984). Similarly, vegetative filter strips 4.6 and $9.1 \mathrm{~m}$ wide removed $59 \%$ to $82 \%$ and $63 \%$ to $76 \%$ of $\mathrm{P}$ and N, respectively (DILLAHA et al., 1989). Studies show that sediment trapping efficiency increases with width but, increasing the width beyond 9 to $15 \mathrm{~m}$ has less effect (ABUZREIG et al., 2003; ROBINSON et al., 1996). In contrast, some other studies have shown lower removal efficiencies as compared to the above studies. For example, PETERSON and VONDRACEK (2006) showed narrow buffers were less effective when modeled for total $\mathrm{N}$ and $\mathrm{P}$ filtration. Comparing filter strip performance over ten years, DOSSKEY et al. (2007) showed less than $50 \%$ reductions in $\mathrm{N}$ and $\mathrm{P}$.

In the Midwest USA, about four million ha of claypan soils in Missouri and Illinois are identified as Major Land Resource Area 113 (USDA-NRCS, 2006). These soils have a shallow top soil horizon underlain by a 13 to $46 \mathrm{~cm}$ deep argillic horizon with clay contents exceeding $450 \mathrm{~g} \bullet \mathrm{kg}^{-1}$. Water and solute permeability is extremely low in these soils due to lower saturated hydraulic conductivity $\left(0.002 \mathrm{~mm} \bullet \mathrm{h}^{-1}\right)$, as compared to the surface horizons (BLANCO-CANQUI et al., 2002). Additionally, the depth to the claypan varies across fields; the claypan is nearer to the surface for eroded soils (WANG et al., 2003). Perched water in the surface horizons caused by the relatively low hydraulic conductivity of the claypan potentially makes these soils more susceptible to nutrient loss (MOTAVALLI et al., 2003; SEOBI et al., 2005). For example, in a simulated rainfall study, ZHENG et al. (2004) observed that $\mathrm{NO}_{3}^{-}$loss was mainly controlled by the near-surface hydraulic gradient. The first recharge event following fertilizer application, irrespective of the time interval between the application and recharge events, transported 
substantial quantities of $\mathrm{NO}_{3}^{-}$through the claypan to ground water (KELLY and POMES, 1998). Therefore, information on nutrient and chemical transport in claypan soils is crucial to evaluate potential water contamination from agricultural sources.

Rainfall distribution is an important determinant of nutrient loss from agricultural land. Nutrient losses associated with above normal precipitation conditions contribute to significant water pollution. Studies in the USA, UK, and Nigeria showed that the largest 2-5 rainfall events were responsible for over $70 \%$ of the annual $\mathrm{N}, \mathrm{P}$, and sediment loss (EDWARDS and OWENS, 1991; LAL, 1976; MORGAN et al., 1987; UDAWATTA et al., 2004). Both the amount and timing of precipitation events relative to fertilizer application, ground cover condition, and the growth condition of the crop affect the amount of nutrient loss. Comparing annual rainfall with runoff and sediment loss from agricultural watersheds, UDAWATTA et al. (2006b) observed that narrow grass strips along streams were effective in reducing losses in years with below normal precipitation but failed during years with above normal rainfall.

While the benefits of perennial vegetative areas in agricultural watersheds have been recognized, there is little information demonstrating relative advantage of varying buffer, grass and grass filter strip conditions and land use on $\mathrm{P}$ and $\mathrm{N}$ losses from watersheds in the Midwest claypan region. An understanding of the interactions among soils, plants and management factors at a watershed scale is crucial for the development of effective environmental management practices (NORD and LYON, 2003). Such information could play an important role in controlling nutrient loss from agricultural watersheds by helping develop guidelines to protect water quality. Nutrient removal capability of perennial vegetation depends, however, on vegetation-soil interactions and input levels (LOWRANCE et al., 1997). Therefore, perennial vegetative areas within a watershed may vary regionally and by land use, management, precipitation, flow rate, and season which alter stream water chemistry. We examined the effect of land use and influence of grass filter strips as well as rainfall on discharge of total phosphorus (TP), total nitrogen, and $\mathrm{NO}_{3}-\mathrm{N}$, using eight first order watersheds with varying proportions of forest, pasture and agricultural land use.

\section{MATERIALS AND METHODS}

\subsection{Study area and watershed characteristics}

Study watersheds are located in Adair and Macon Counties, Missouri, USA $\left(39^{\circ} 50^{\prime} \mathrm{N}\right.$ to $40^{\circ} 05^{\prime} \mathrm{N}$ and $90^{\circ} 32^{\prime} \mathrm{W}$ to $\left.92^{\circ} 20^{\prime} \mathrm{W}\right)$ (Figure 1). Details on watershed characteristics, soils, weather, and water sampling procedures can be found in UDAWATTA et al. (2006b). In brief, three land use types were included: at one extreme, forest catchments $(n=2)$ and at the other extreme, row-crop $(n=3)$ catchments with virtually no riparian vegetation, and pasture/Conservation Reserve Program (CRP) catchments $(\mathrm{n}=3)$ as the intermediate condition. The two forest catchments were within the state-owned Atlanta Conservation Area. Study watersheds ranged in area from 21 to $259 \mathrm{ha}$, and management within each watershed is summarized in table 1 . Watershed areas were estimated using 1:24,000 maps and land use patterns were obtained from annual aerial photographs. Ground truthing was conducted to verify land use within each watershed. Watersheds were identified based on major land management types: forest $(1 \mathrm{xx})$, pasture $(2 \mathrm{xx})$ and row-crop (3xx). One row-crop watershed (400) received irrigation water from the La Plata Water Treatment Plant. This watershed does not have a forested riparian buffer zone, but has a 3 to $4 \mathrm{~m}$ wide dense grass filter strip along the stream, and identified as a row-crop watershed with a grass filter strip (RC-GFS).

The main crops in these watersheds were corn (Zea mays L.) and soybean (Glycine max (L.) Merr.) in rotation and under minimum or no-till cultivation. Wheat and sorghum represented little land cover in row-crop watersheds. Pasture/CRP watersheds were mainly under CRP. Fescue (Festuca spp.), golden rod (Solidago spp.) and cool season grasses were common in pasture watersheds.

The average snowfall in the study area is about $61 \mathrm{~mm}$ of water equivalent and generally lasts several weeks. The average winter temperature is $-2.2^{\circ} \mathrm{C}$ and average daily minimum is $-7.7^{\circ} \mathrm{C}$. In summer, the average temperature is $23.9^{\circ} \mathrm{C}$ and average daily maximum is $30^{\circ} \mathrm{C}$. The 30 -years precipitation averages $967 \mathrm{~mm}$ about 65\% of which falls in April through September (OWENBY and EZELL, 1992). During the three years in the study, precipitation amounts were 829, 1,315 and $803 \mathrm{~mm}$ in 1997, 1998, and 1999, respectively. These amounts represent $86 \%, 136 \%$, and $83 \%$ of the long-term precipitation in respective years.

\subsection{Sample collection and analysis}

All eight watersheds were instrumented with ISCO water samplers, flow measuring devices (Lincoln, NE, USA), and marine batteries. Runoff water samples were collected for three consecutive years (1997-1999) after each runoff event. Streams were surveyed and stream parameters were fitted into Manning's equations to estimate flow. Flow data were recorded at 10 minute intervals. After a runoff event, flow rate, flow level and sample intake time data from the recording devices were downloaded to a laptop computer. Water samples were 


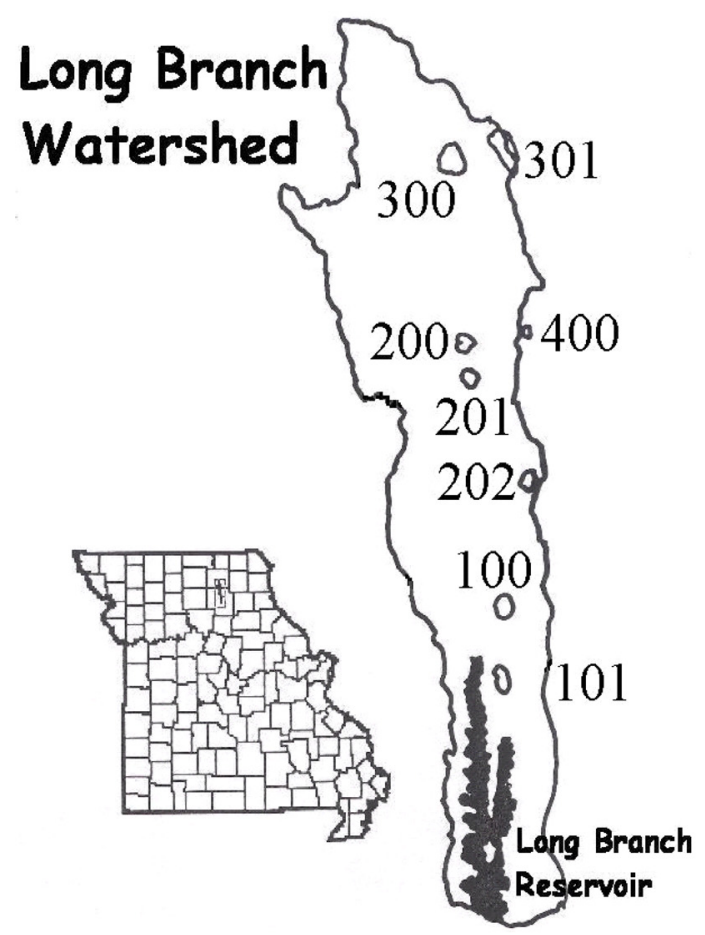

Figure 1. Long Branch Watershed in Macon and Adair counties of Missouri, USA and approximate location of eight watersheds within the Long Branch watershed (After UDAWATTA et al., 2006b).

Bassin versant de Long Branch des comtés de Macon et Adair, Missouri, États-Unis, et localisation des huit sous-bassins à l'étude.

Table 1. Area and land use composition of eight study watersheds in Adair and Macon Counties, Missouri, USA. Superficies des occupations du sol des huit bassins à l'étude des comtés de Macon et Adair, Missouri, États-Unis.

\begin{tabular}{|c|c|c|c|c|c|}
\hline & & \multirow{3}{*}{$\begin{array}{c}\text { Area } \\
\text { ha }\end{array}$} & \multicolumn{3}{|c|}{ Land use composition } \\
\hline \multicolumn{2}{|c|}{ Watershed } & & \multirow{2}{*}{ Forest } & \multirow{2}{*}{$\begin{array}{c}\text { Pasture } \\
\%\end{array}$} & \multirow[t]{2}{*}{ Row-crop } \\
\hline & & & & & \\
\hline \multirow[t]{2}{*}{ Forest } & 100 & 65 & 84 & 2 & 12 \\
\hline & 101 & 87 & 94 & 0 & 4 \\
\hline \multirow[t]{3}{*}{ Pasture } & 200 & 70 & 28 & 66 & 6 \\
\hline & 201 & 30 & 43 & 57 & 0 \\
\hline & 202 & 26 & 18 & 41 & 41 \\
\hline \multirow[t]{2}{*}{ Row-crop } & 300 & 140 & 7 & 7 & 86 \\
\hline & 301 & 259 & 4 & 22 & 74 \\
\hline RC-GFS & $(400)$ & 21 & 0 & $<1$ & 100 \\
\hline
\end{tabular}


transfered from the field to the laboratory and individual samples were analyzed for water quality parameters. Flow rates corresponding to samples, time intervals and nutrient concentrations were used to calculate total loss for runoff events.

Unprocessed samples were refrigerated at $4^{\circ} \mathrm{C}$ until analysis. TP, TN, and $\mathrm{NO}_{3}{ }^{-} \mathrm{N}$ were determined on a Lachat QuickChem-2000 Auto Analyzer (Milwaukee, WI, USA). Total phosphorus was determined by ascorbic acid-molybdate procedure on unfiltered samples following ammonium peroxidisulfate digestion (LIAO and MARTEN, 2000). The detection limit for the method was $0.9 \mu \mathrm{g} \bullet \mathrm{L}^{-1}$. TN was determined using cadmium reduction on unfiltered samples following potassium perusulfate digestion (PRITZLAFF, 1999a). TP, TN and $\mathrm{NO}_{3}{ }^{-} \mathrm{N}$ (PRITZLAFF, 1999b) were determined as outlined by Lachat Quickchem Methods 10-115-01-1-F, 10-107-04-1-C, and 10-107-04-1-B, respectively. The detection limit for the $\mathrm{TN}$ and $\mathrm{NO}_{3}{ }^{-} \mathrm{N}$ methods was $\leq 0.002 \mathrm{mg} \bullet \mathrm{L}^{-1}$. Quality control for the Lachat analyzer was maintained by randomly positioning three control standards with differing concentrations, four duplicate samples and one quality control sample in each tray (90 samples). All samples with suspected and unacceptable concentrations were reanalyzed.

\subsection{Statistical analysis}

Random variables were analyzed as a split-plot intime using the PROC MIXED procedure in SAS. The main plot consisted of land management (treatments) and the subplot consisted of year and interaction of land management*year. Watersheds within a treatment were used as the denominator of $\mathrm{F}$ for the main plot (land management) effect. Watersheds within a land management and year were used as the denominator of $\mathrm{F}$ for the sub-plot (year and interaction of land management ${ }^{*}$ year) effects. The residual mean square represented multiple observations within a year watershed combination. The fixed effects are land management, year and the interaction of land management* ${ }^{*}$ ear. Mean differences were determined using Fisher Least Significance (LSD) and were calculated using LS-Means statement within the PROC MIXED procedure. The variance covariance matrix was investigated using AIC coefficient to determine the most suitable mean separation procedure. Differences in TP, TN and $\mathrm{NO}_{3}{ }_{3} \mathrm{~N}$ among land use types were declared significant at the $\alpha=0.05$ level.

\section{RESULTS}

\subsection{Total phosphorus loss}

Among the studied land uses, the row-crop land use consistently had the largest TP losses during the study. The annual TP losses on row-crop land use, in decreasing order, were 5.37, 3.27 and $2.84 \mathrm{~kg} \mathrm{ha}^{-1}$ in years 1998,1997 and 1999, respectively. These watersheds lost 26, 8 and 4 times more TP than the forest land use in 1997, 1998 and 1999 respectively, and the losses significantly differed $(p \leq 0.001)$ (Table 2). These losses were 3, 6 and 11 times greater than losses on pastures. RC-GFS lost only $15 \%, 42 \%$, and $41 \%$ of TP that was lost on the two row-cropped land use in 1997 ,

Table 2. Three-year mean annual and individual year's total phosphorus loss on the eight watersheds from 1997 to 1999. Pertes annuelles et moyenne en phosphore des huit bassins pour la période 1997-1999.

\begin{tabular}{|c|c|c|c|c|c|}
\hline & & \multirow{3}{*}{3 -year } & \multicolumn{3}{|c|}{ Year } \\
\hline \multicolumn{2}{|c|}{ Watershed } & & 1997 & 1998 & 1999 \\
\hline & & & \multicolumn{3}{|c|}{$\mathrm{kg} \cdot \mathrm{ha}^{-1} \bullet \mathrm{yr}^{-1}$} \\
\hline \multirow{3}{*}{ Forested } & 100 & 0.55 & 0.15 & 0.86 & 0.65 \\
\hline & 101 & 0.31 & 0.11 & 0.52 & $\dagger$ \\
\hline & Mean & 0.43 & 0.13 & 0.69 & 0.65 \\
\hline \multirow[t]{4}{*}{ Pastured } & 200 & 0.72 & 0.63 & 1.45 & 0.10 \\
\hline & 201 & 1.29 & 0.71 & 1.87 & $\dagger$ \\
\hline & 202 & 0.68 & 0.18 & 1.46 & 0.40 \\
\hline & Mean & 0.90 & 0.51 & 1.59 & 0.25 \\
\hline \multirow[t]{3}{*}{ Row-cropped } & 300 & 4.22 & 3.89 & 5.50 & 3.28 \\
\hline & 301 & 3.43 & 2.66 & 5.23 & 2.40 \\
\hline & Mean & 3.82 & 3.27 & 5.37 & 2.84 \\
\hline RC-GFS & & 1.30 & 0.50 & 2.25 & 1.15 \\
\hline
\end{tabular}

$\dagger$ Not sampled 
1998 and 1999 respectively, and these losses were significantly different $(\mathrm{p} \leq 0.05)$.

The pasture land use lost $0.5,1.59$ and $0.25 \mathrm{~kg} \mathrm{TP} \bullet \mathrm{ha}^{-1}$ in 1997, 1998 and 1999. Pasture land use lost four and two times more TP in 1997 and 1998, compared to the forest land use (Table 2). The losses on the pasture land use were only $15 \%, 30 \%$ and $9 \% \mathrm{TP}$, compared to the losses on the row-crop land use in 1997, 1998 and 1999 respectively. Pasture and RC-GFS land use types lost almost the same amount of TP in 1997 (0.502 and $0.504 \mathrm{~kg} \bullet \mathrm{ha}^{-1} \bullet \mathrm{yr}^{-1}$, respectively).

The three-year mean annual TP loss on watersheds ranged between 0.31 to $4.22 \mathrm{~kg} \bullet \mathrm{ha}^{-1} \bullet \mathrm{yr}^{-1}$ and were strongly correlated to land use, but differed within a land cover type (Table 2). Forest, pasture, and row-crop land use types lost $0.43,0.90$ and $3.83 \mathrm{~kg} \mathrm{TP} \bullet \mathrm{ha}^{-1}$ respectively, during the study (Figure 2). The row-crop land use lost nine and four times more TP than forest and pasture land use types, respectively and the differences were significantly different $(p \leq 0.001)$. The RC-GFS watershed $\left(1.30 \mathrm{~kg} \bullet \mathrm{ha}^{-1} \bullet \mathrm{yr}^{-1}\right)$ lost only $34 \%$ of the TP loss that occurred on row-crop land use and the losses were significantly different $(p \leq 0.003)$. Pasture land use lost only two times more TP compared to the loss from the forest land use, and these losses were not significantly different.

\subsection{Total nitrogen loss}

Annual watershed TN loss ranged from 0.72 on a forested to $34.19 \mathrm{~kg} \bullet \mathrm{ha}^{-1}$ on a row-crop watershed (Table 3). Similar to the TP loss, the largest losses were observed on row-crop watersheds. In 1997, row-crop land use lost 35, 15 and three times more TN than forest, pasture and RC-GFS land use types, and these losses were significantly different $(p \leq 0.05)$ (Table 3). Total nitrogen losses between the row-cropped and RC-GFS were not significantly different $(p \leq 0.05)$ in 1998. Total nitrogen losses between forest and row-crop, pasture and row-crop, as well as RC-GFS and row-crop, were significantly different $(p \leq 0.05)$ in 1999 .

The RC-GFS watershed lost 9.64, 16.41 and $10.86 \mathrm{~kg} \mathrm{TN} \bullet \mathrm{ha}^{-1}$ in 1997, 1998 and 1999, and these were significantly $(p \leq 0.05)$ lower than that on row-crop land use. Compared to forest and pasture land use types, the RC-GFS watershed lost three to four times more TN during the study.

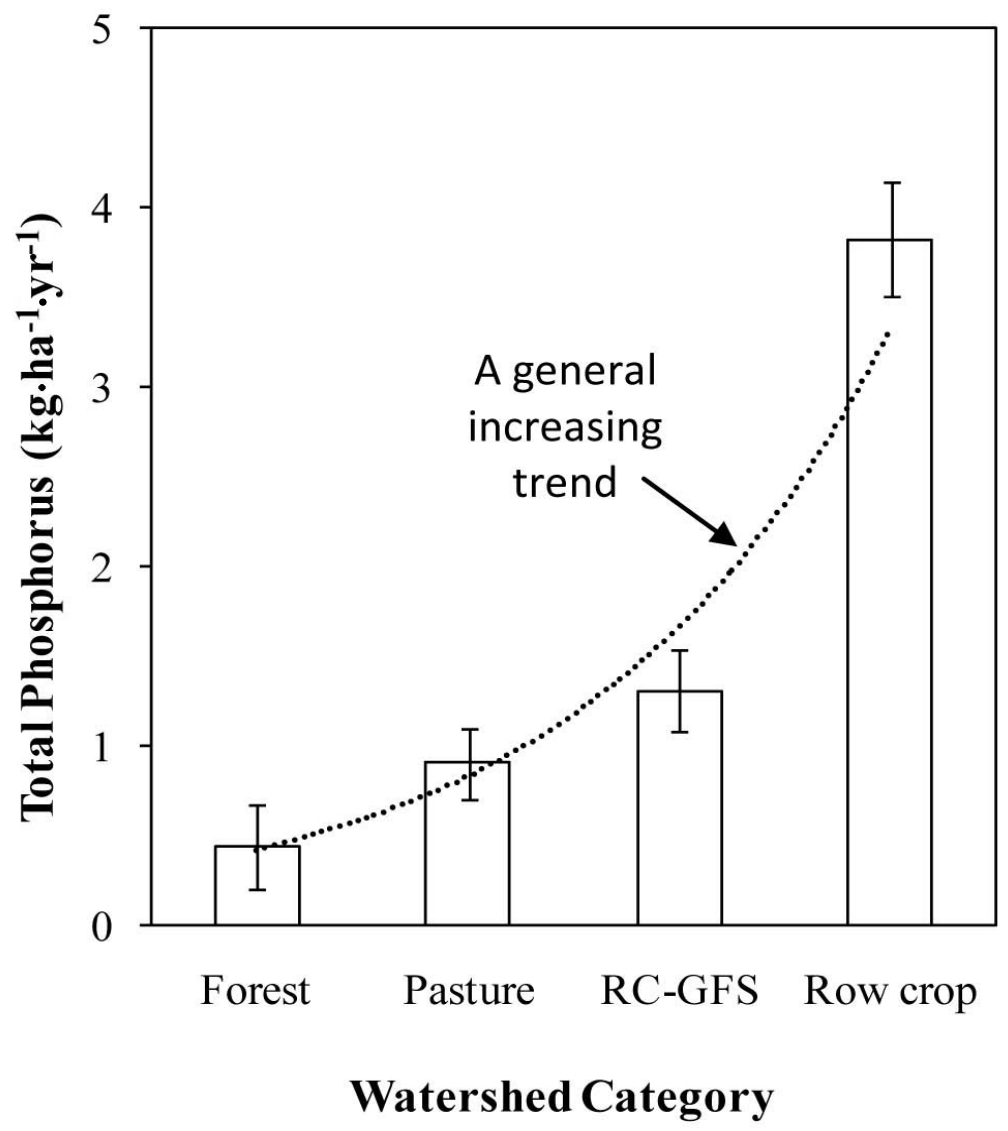

Figure 2. The mean total phosphorus loss for forest, pasture, row-crop grass filter strip (RC-GFS), and row-crop land use. Perte moyenne en phosphore total des occupations forêt, pâturage et culture à interligne avec (RC-GFS) et sans voies engazonnées. 
In 1997, 1998 and 1999, the RC-GFS watershed lost only $30 \%, 54 \%$ and $42 \%$ of the TN loss on row-crop land use respectively. RC-GFS watershed lost 11 , five and six times more TN than forest land use in 1997, 1998 and 1999, respectively, while the row-crop land use lost 35, 11 and 14 times more TN than the forest land use.

Three-year mean and annual TN losses from watersheds indicated the influence of land use. Mean $\mathrm{N}$ losses varied from 1.50 (101) to $29.26(301) \mathrm{kg} \bullet \mathrm{ha}^{-1} \bullet \mathrm{yr}^{-1}$ among individual watersheds (Table 3). Forest land use had the lowest TN loss $\left(2.02 \mathrm{~kg} \bullet \mathrm{ha}^{-1} \bullet \mathrm{yr}^{-1}\right)$, while row-crop land use had the greatest loss (29.25 $\mathrm{kg}^{\bullet} \mathrm{ha}^{-1} \bullet \mathrm{yr}^{-1}$ ) (Figure 3). Total nitrogen losses between forest and row-crop as well as pasture and row-crop land use types were significantly different $(p \leq 0.001)$ (Figure 3 ). Forested watersheds lost only $50 \%$ of the TN that was lost on the pastured watersheds, and the losses between these land use types were not significantly different $(p \leq 0.05)$.

Table 3. Three-year mean annual and individual year's total nitrogen loss on the eight watersheds from 1997 to 1999. Pertes annuelles et moyenne en azote des huit bassins pour la période 1997-1999.

\begin{tabular}{|c|c|c|c|c|c|}
\hline & & \multirow{3}{*}{ 3-year } & \multicolumn{3}{|c|}{ Year } \\
\hline \multicolumn{2}{|c|}{ Watershed } & & 1997 & 1998 & 1999 \\
\hline & & & \multicolumn{3}{|c|}{$\mathrm{kg} \cdot \mathrm{ha}^{-1} \bullet \mathrm{yr}^{-1}$} \\
\hline \multirow[t]{3}{*}{ Forested } & 100 & 2.41 & 1.09 & 4.25 & 1.90 \\
\hline & 101 & 1.50 & 0.72 & 2.27 & $\dagger$ \\
\hline & Mean & 2.02 & 0.91 & 3.26 & 1.90 \\
\hline \multirow[t]{4}{*}{ Pastured } & 200 & 2.38 & 1.54 & 4.86 & 0.75 \\
\hline & 201 & 7.28 & 2.49 & 12.07 & $\dagger$ \\
\hline & 202 & 3.35 & 2.53 & 4.97 & 2.55 \\
\hline & Mean & 4.34 & 2.19 & 7.30 & 1.65 \\
\hline \multirow[t]{3}{*}{ Row-cropped } & 300 & 29.24 & 34.19 & 36.05 & 17.48 \\
\hline & 301 & 29.26 & 29.32 & 24.27 & 34.19 \\
\hline & Mean & 29.25 & 31.75 & 30.16 & 25.83 \\
\hline RC-GFS & & 12.31 & 9.64 & 16.41 & 10.86 \\
\hline
\end{tabular}

$\dagger$ Not sampled

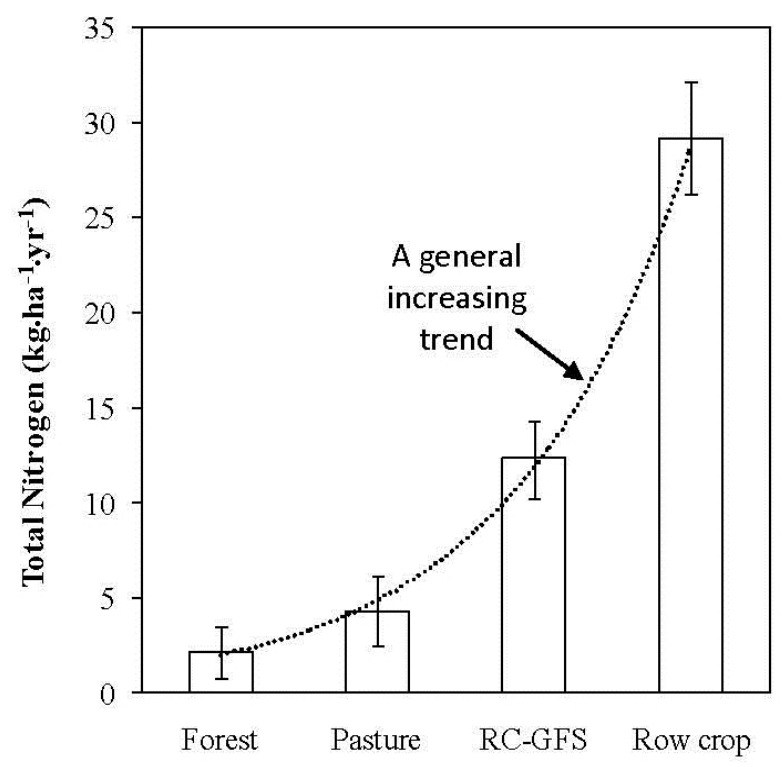

Watershed Category

Figure 3. The mean total nitrogen loss for forest, pasture, row-crop grass filter strip (RC-GFS), and rowcrop land use.

Perte moyenne en azote total des occupations forêt, pâturage et culture à interligne avec (RC-GFS) et sans voies engazonnées. 
Row-cropped watersheds lost 13, seven and two times more TN compared to forest, pasture, and RC-GFS land use types respectively (Figure 3). A comparison of three-year mean and annual TN losses between the RC-GFS and other land use types shows the influence of grass filter strips on reducing nutrient loss from agricultural watersheds. The three-year mean TN loss between the row-crop and RC-GFS were significantly different $(p \leq 0.01)$, and the RC-GFS watershed lost only $42 \%$ of the loss that occurred on row-cropped watersheds.

\subsection{Nitrate-nitrogen $\left(\mathrm{NO}_{3}^{-} \mathrm{N}\right)$ loss}

The annual $\mathrm{NO}_{3}-\mathrm{N}$ loss on watersheds followed a pattern similar to $\mathrm{TN}$ loss. In each year, row-crop land use lost significantly more nitrate than forest and pasture land use types. Additionally, the RC-GFS watershed lost significantly less nitrate than the row-crop land use, but significantly more than the forest land use in each year of the study. Although, pasture land use had lower losses than the RC-GFS for two years, the loss in 1997 was similar on both RC-GFS and pastured watersheds.

The three-year mean $\mathrm{NO}_{3}{ }^{-} \mathrm{N}$ loss also showed a trend similar to TN loss (Figures 2 and 3). The forest $\left(0.36 \mathrm{~kg} \bullet \mathrm{ha}^{-1} \bullet \mathrm{yr}^{-1}\right)$ land use had the lowest $\mathrm{NO}_{3}{ }^{-} \mathrm{N}$ loss while

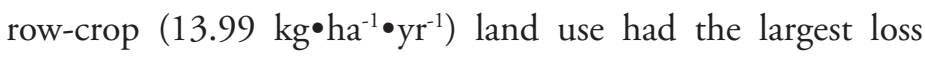
(Table 3). The row-crop land use lost significantly $(p \leq 0.001)$ more $\mathrm{NO}_{3}{ }^{-} \mathrm{N}$ than the forest and pasture land use types (Figure 4). The three-year mean $\mathrm{NO}_{3}{ }^{-} \mathrm{N}$ losses between forest and RC-GFS, pasture and RC-GFS as well as row-crop and RC-GFS were significantly different $(\mathrm{p} \leq 0.05)$. Forest, pasture and RC-GFS land use types lost only 2.6, 4.6 and 52\% of the loss that occurred on the row-crop land use. Row-crop, pasture and RC-GFS land use types lost 39, 1.8 and 20 times more $\mathrm{NO}_{3}{ }^{-} \mathrm{N}$ compared to the forest land use.

\section{DISCUSSION}

There was a marked difference in TP, TN and nitrate losses associated with year to year variation in weather (Tables 2, 3 and 4). The variability among watersheds, within a category, was also larger in 1998 as compared to 1997 . Row-cropped watersheds lost 1.8 times more TP $(300=1.42$ and $301=1.97)$ in 1998 as compared to values in 1997. Individual watersheds in the forest, pasture, and RC-GFS land use types lost two to eight times more TP in 1998 than 1997. With increasing precipitation, forest (5.4), pasture (3.2) and RC-GFS (4.5)

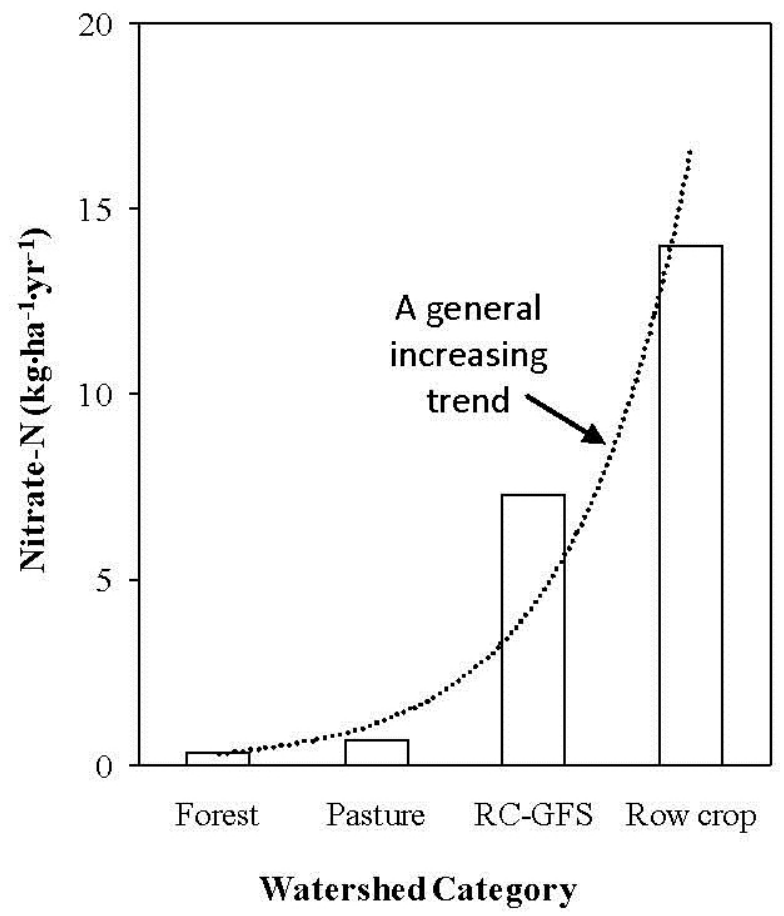

Figure 4. The mean nitrate-nitrogen loss for forest, pasture, row-crop grass filter strip (RC-GFS) and row-crop land use.

Perte moyenne en azote-nitrate des occupations forêt, pâturage et culture à interligne avec (RC-GFS) et sans voies engazonnées. 
Table 4. Three-year mean annual and individual year's nitrate-nitrogen loss on the eight watersheds from 1997 to 1999. Pertes annuelles et moyennes en azote-nitrate des huit bassins pour la période 1997-1999.

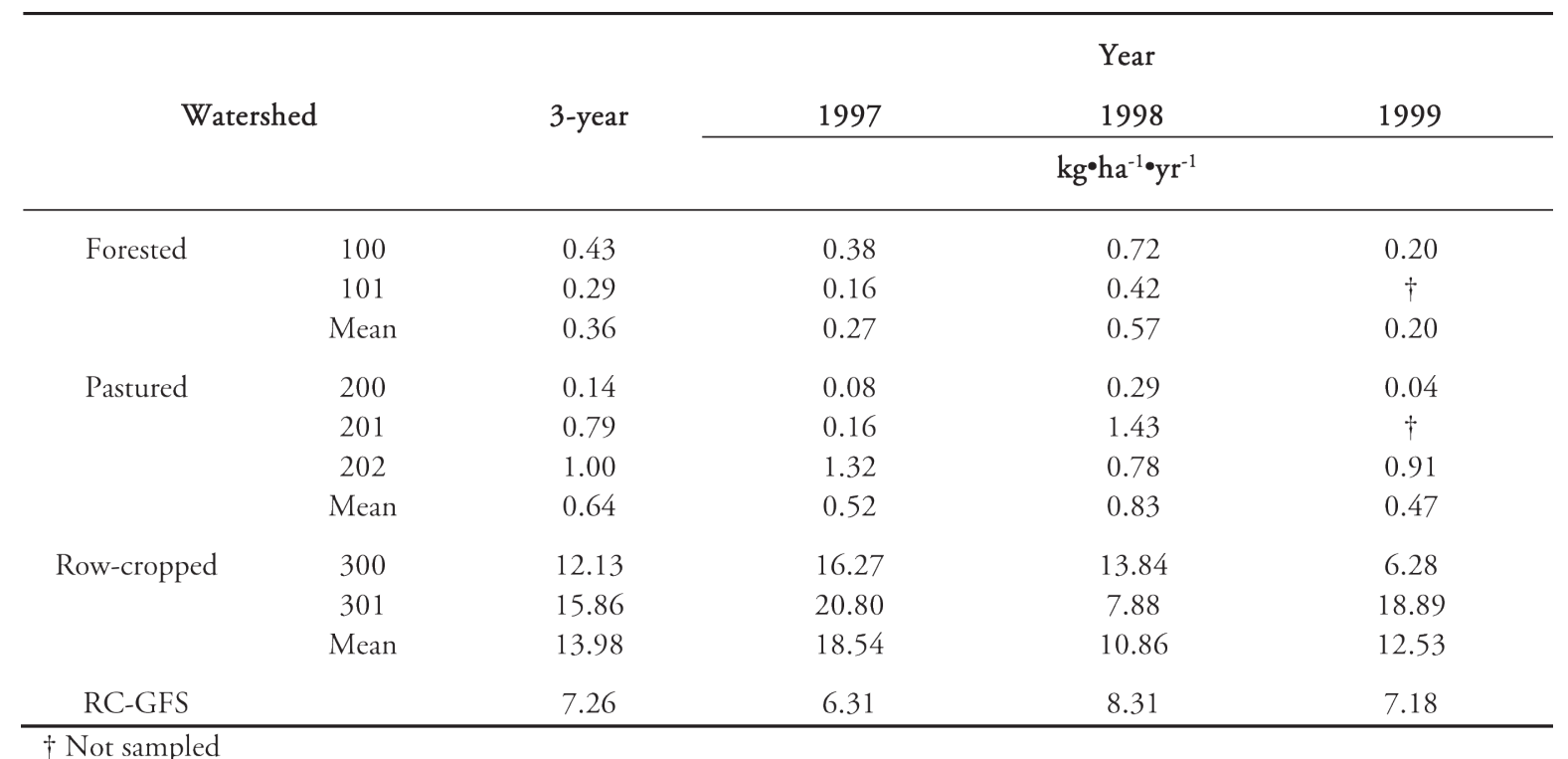

land use types, on average, lost more than four times TP in 1998 compared to the losses in 1997. In contrast, row-cropped watersheds lost only twice as much TP in 1998 compared to 1997. Year-to-year, TP loss on watersheds indicates that even less than average precipitation conditions caused severe loss of TP on row-cropped watersheds than other land use types.

Annual $\mathrm{P}$ discharges reviewed by BEAULAC and RECKOW (1982) averaged around $0.2 \mathrm{~kg} \bullet \mathrm{ha}^{-1}$ for forests, $1 \mathrm{~kg} \bullet \mathrm{ha}^{-1}$ for pasture, and $2 \mathrm{~kg} \bullet \mathrm{ha}^{-1}$ for row-crops. Forested watersheds in this study lost twice as much TP compared to their values. Annual P loss in a seven-year study, with three adjacent corn-soybean rotational watersheds in Northeast

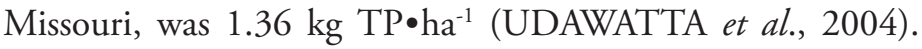
The smaller loss in their study, as compared to this study, was attributed to grass waterways on each watershed. However, UDAWATTA et al. (2004) also observed $2.86 \mathrm{~kg}$ TP $\bullet \mathrm{ha}^{-1}$ loss in 1993 when the area received $42 \%$ more precipitation than the long-term mean. Total P losses on the RC-GFS watershed and those reported by UDAWATTA et al. (2004) were in the same range demonstrating the beneficial effects of grass strips on row-crop management.

Total nitrogen loss from individual watersheds was greater in 1998 compared to losses in 1997 and 1999, except for the watershed 301. We did not collect samples from watershed 301 for the July 4, 1998 runoff event since the flow meter and the sampler were damaged by lightening. This was the largest runoff event during the entire study period which generated $3 \mathrm{~m}$ of flow in the stream near the sampler location of watershed 301. The estimated TN loss in 1998, on watershed 301, was $30.91 \mathrm{~kg} \bullet \mathrm{ha}^{-1} \bullet \mathrm{yr}^{-1}$ (1997 loss on $301^{*}(1998$ loss on 300/1997 loss on 300)) and it increased the 1998 annual loss to $33.48 \mathrm{~kg} \bullet \mathrm{ha}^{-1} \cdot \mathrm{yr}^{-1}$ for the row-crop land use. The study area received $16 \%$ less precipitation in 1997 and 1999 than the 30-year average. In 1998, the study area received 36\% more precipitation than the 30 -year average and all land use types lost more nutrients. Results varied somewhat among years due to differences in rainfall distribution, crop rotation, and cropping practices. Nevertheless, seasonal trends in nutrient discharge were parallel for all three years.

Total nitrogen and nitrate loss agree with previous research on similar soils, sites and management conditions. BURWELL et al. (1976) observed TN losses of 14 to $50 \mathrm{~kg}^{\bullet} \mathrm{ha}^{-1} \bullet \mathrm{yr}^{-1}$ in a 13-year study in Northwestern Missouri. Their smallest loss was on brome grass-pasture lands and the maximum loss was on corn-soybean watersheds. In their study, the watershed which lost the maximum amount of $\mathrm{N}$ received $448 \mathrm{~kg} \mathrm{~N} \bullet \mathrm{ha}^{-1} \bullet \mathrm{yr}^{-1}$ for three consecutive years. Another corn-soybean watershed,

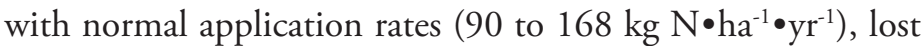
only $27.8 \mathrm{~kg} \mathrm{~N} \bullet \mathrm{ha}^{-1} \bullet \mathrm{yr}^{-1}$ during the 13 -year study. Annual $\mathrm{N}$ loss ranged from 17.1 to $19.2 \mathrm{~kg} \bullet \mathrm{ha}^{-1}$ with a $16.4 \mathrm{~kg} \bullet \mathrm{ha}^{-1}$ mean in a seven-year study with three corn-soybean watersheds in Northeast Missouri (UDAWATTA et al., 2006a). In the Long Branch watersheds, TN loss on row-crop land use was intermediate as compared to BURWELL et al. (1976) and larger than UDAWATTA et al. (2006a). Nitrate-N losses from the row-cropped watersheds were comparable to the annual $\mathrm{NO}_{3}{ }^{-} \mathrm{N}$ loss in runoff from a seven-year corn-soybean rotation study at the Greenley Center in Novelty, Missouri (11 $\left.\mathrm{kg} \bullet \mathrm{ha}^{-1} \bullet \mathrm{yr}^{-1}\right)$ (UDAWATTA et al., 2006a). This loss represented approximately $68 \%$ of the total $\mathrm{N}$ during the 
seven-year study. The row-cropped watersheds in Long Branch lost $48 \%$ of the $\mathrm{N}$ as $\mathrm{NO}_{3}{ }^{-} \mathrm{N}$.

Mean $\mathrm{NO}_{3}{ }^{-} \mathrm{N}$ concentration in streamflow was calculated using the total runoff volume and total $\mathrm{NO}_{3}-\mathrm{N}$ loss for each event. The average $\mathrm{NO}_{3}-\mathrm{N}$ concentration for forest, pasture, and row-crop land use types were $0.39,0.50$ and $2.56 \mathrm{mg}^{\bullet} \mathrm{L}^{-1}$ respectively (Figure 5). According to ICE and BINKLY (2003), small forest watersheds on average lose $0.31 \mathrm{mg} \bullet \mathrm{L}^{-1} \mathrm{NO}_{3}{ }^{-} \mathrm{N}$ with values as high as $3.1 \mathrm{mg} \bullet \mathrm{L}^{-1}$, and these values change seasonally. Stream water $\mathrm{NO}_{3}{ }^{-} \mathrm{N}$ concentrations in forested watersheds in this study ranged from 0.009 to $1.97 \mathrm{mg}^{\bullet} \mathrm{L}^{-1}$, compared to 0.001 to $5.85 \mathrm{mg} \cdot \mathrm{L}^{-1}$ on pasture and 0.05 to $15.89 \mathrm{mg} \cdot \mathrm{L}^{-1}$ on row-crop watersheds (Figure 5). Although, overall $\mathrm{NO}_{3}{ }^{-} \mathrm{N}$ concentrations were below the drinking water standards, streams carried appreciable amounts of nitrate during runoff. Compared to the nine events during a seven-year study at the Greenley Research Center (UDAWATTA et al., 2006a), only two events on row-crop watersheds had average concentrations $>10 \mathrm{mg} \mathrm{NO}{ }_{3}^{-} \mathrm{N} \cdot \mathrm{L}^{-1}$. In the Long Branch watershed, those two larger losses were associated with greater precipitation events in 1998, while at the Greenley Center those nine losses were associated with fertilizer application and larger precipitation events.

In this study with $>84 \%$ forest cover, the loss of TP, TN and nitrate on the forest land use were only $11 \%, 7 \%$ and $11 \%$, respectively, of that on the row-crop land use. The influence of perennial vegetation was shown by this study and results corroborate previous research (GILLIAM, 1994; LOWRANCE et al., 1984; MCINTYRE, 1993; PETERJOHN and CORRELL, 1984). If the TN loss on row-crop land use was used as the normal, forest and pasture land use types reduced the TN loss by $92 \%$ and $85 \%$ respectively. The reduction in $\mathrm{NO}_{3}{ }^{-} \mathrm{N}$ by the respective land use types were $89 \%$ and $77 \%$, as compared to row-crop land use. Similar to results from this study, CLAUSEN et al. (2000) and PETERJOHN and CORRELL (1984) observed 70\%, 83\% and 79\% reductions in TN, TKN and $\mathrm{NO}_{3}{ }^{-} \mathrm{N}$ respectively, as runoff moved from cropland through a restored and mature riparian forest. The difference in $\mathrm{N}$ removal among studies could be attributed to soil, site, precipitation and management factors. Our results support the assertion that relationships between nutrients in runoff vary between studies as a function of land use and soil type.

Another reason that may have affected the nutrient loss among land use types is the claypan. Soils in the row-cropped watersheds are underlain by a claypan horizon, as compared to the soils in the forested watersheds. The claypan acts as a barrier directing vertical flow horizontally above the pan, thus generating more runoff from these soils (BLANCO-CANQUI et al., 2002). SCHMITT (1999) observed that pastured and forested land uses had more subsurface flow than row-cropped land uses in the same study watersheds. Therefore, the intact perennial vegetation in forest and pasture watersheds could function as a sink for removal and long-term storage of nutrients from agricultural systems. In contrast, degraded riparian buffer conditions on row-cropped watersheds with sparsely distributed vegetation short circuit runoff water and shorten the residence time due to rapid transport through the riparian forest, which reduces the efficiency of nutrient removal prior to entering into streams. Because attenuation is well correlated with water table depth, temporal and spatial variations in water table depth strongly influence nitrate removal. Marked difference in filtration among forest and pasture zones can be attributed to spatial and temporal variations in soil type, organic matter content, hydrology and vegetation.
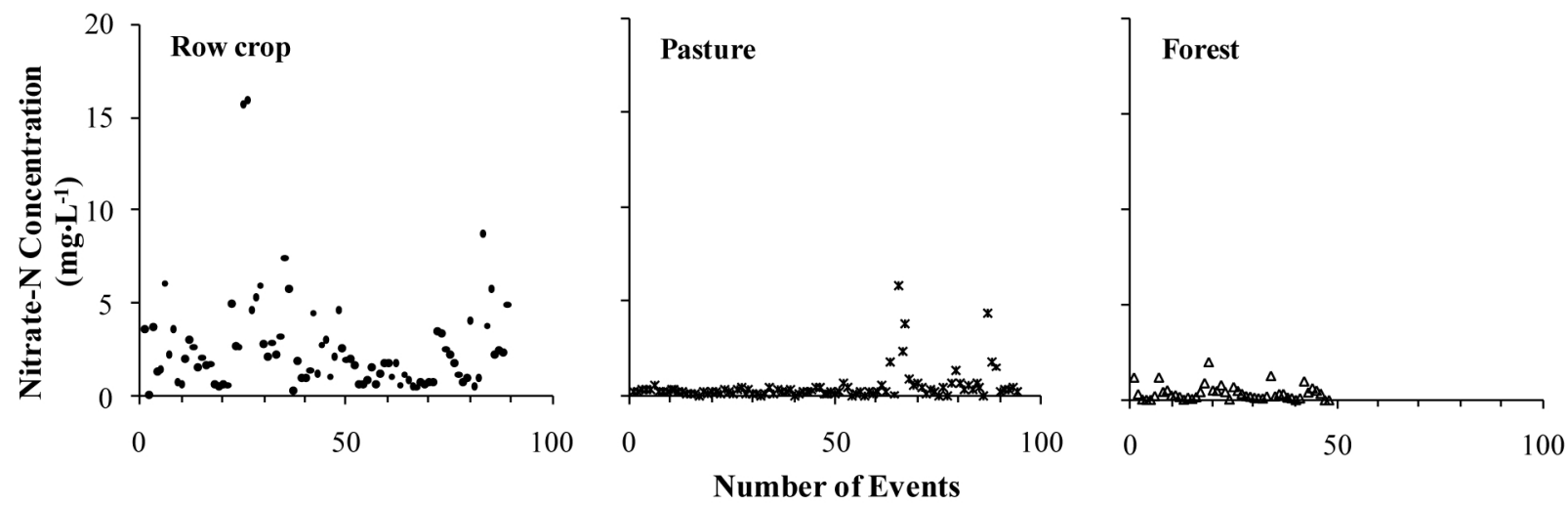

Figure 5. Flow-weighted mean nitrate- $\mathrm{N}$ concentration by runoff event during the study period for forest, pasture, and row-crop watersheds.

Concentration moyenne (pondérée selon le débit) en $N$-nitrate dans le ruissellement événementiel pour la période à l'étude dans les bassins forestier, en pâturage et en culture à interligne. 
Results show that overall TP, TN and $\mathrm{NO}_{3}{ }^{-} \mathrm{N}$ loss from RC-GFS was only $34 \%, 42 \%$, and $34 \%$ respectively, of that from row-crop land use. Although, studies have shown that increasing buffer width beyond $15 \mathrm{~m}$ does not remove nutrients effectively (DILLAHA et al., 1989), results of this study suggest that pasture areas placed in between the stream and row-crop cover within a watershed was effective in filtering nutrients in runoff. Vegetation, such as stems and grass roots, efficiently reduces runoff flow, enhances settling of sediment and reduces erosion (SCHMITT et al., 1999). Grass roots enhance soil properties, and thus infiltration. Additionally, plant uptake removes $\mathrm{P}$ in the soil solution, resulting in increased $\mathrm{P}$ adsorption capacity and increased $\mathrm{P}$ retention in soils (LYONS et al., 1998).

Better infiltration rates and greater residence time of runoff under perennial vegetation seem to have removed more nutrients from surface and subsurface water before it enters the stream. The study clearly indicates that all row-cropped watersheds lack effective measures to protect stream water quality. Because perennial vegetation reduces the impact on water resources by reducing non-point source losses, converting highly vulnerable areas to perennial vegetation may help reduce nutrient loss from row-cropped watersheds. Such areas could be located near streams, other areas within a watershed, or variable source areas.

\section{CONCLUSIONS}

A better understanding of the land use, environmental, and management influences that govern nutrient loss from agricultural watersheds provides important information to develop management guidelines to reduce these losses. The results show that TP, TN and $\mathrm{NO}_{3}{ }^{-} \mathrm{N}$ loss in runoff in a typical Midwestern U.S. corn-soybean rotation were affected by land use and precipitation. Significantly, small nutrient losses were observed from the forested watersheds while the largest losses were observed from row-cropped watersheds. Pasture land use in row-cropped watersheds reduced nutrient losses compared to the losses on row-cropped watersheds. The filter strips along the stream on a row-cropped watershed also reduced nutrient losses when compared to losses on row-cropped watersheds.

These results have important implications for the management of agricultural watersheds. Emphasis should be placed on management strategies that reduce runoff, sediment, and nutrient losses. Our results show that intact riparian buffer, pasture land within a row-cropped watershed and grass filter strips exhibit significant capacity to reduce nutrient transport in runoff and these provide a way to improve surface water quality in agricultural areas. Relationships between spatial distribution of each land use type and nutrient loss has yet to be developed.

\section{ACKNOWLEDGEMENTS}

The authors thank Missouri Department of Natural Resources for funding and supporting this study in a variety of ways. We especially thank landowners for their permission to install water sampling instruments and to collect samples for three consecutive years. Special thanks to Stephen Schmitt, Kwang Guk An and Stephen Allen for field and laboratory assistance.

\section{BIBLIOGRAPHICAL REFERENCES}

ABU-ZREIG M., R.P. RUDRAR, H.R. WHITELEY, M.N. LALONDE and N.K. KAUSHIK (2003). Phosphorus removal in vegetated filter strips. J. Environ. Qual., 32, 613-619.

BEAULACM.N. and K.H. RECKOW (1982). An examination of land use-nutrient export relationships. Water Resour. Bull., 18, 1013-1022.

BLANCO-CANQUI H., C.J. GANTZER, S.H. ANDERSON, E.E. ALBERTS and F. GHIDEY (2002). Saturated hydraulic conductivity and its impact on simulated runoff for claypan soils. Soil Sci. Soc. Am. J., 66, 1596-1602.

BURWELL R.E., G.E. SCHUMAN, K.E. SAXTON and H.G. HEINEMANN (1976). Nitrogen in subsurface discharge from agricultural watersheds. J. Environ. Qual., 5, 325-329.

CLAUSEN J.C., K. GUILLARD, C.M. SIGMUND and K.M. DORS (2000). Water quality changes from riparian buffer restoration in Connecticut. J. Environ. Qual., 29, 1751-1761.

COULTER C.B., R.K. KOLKA and J.A. THOMPSON (2004). Water quality in agricultural, urban, and mixed land use watersheds. J. Am. Water Resour. Assoc., 40, 1593-1601.

DILLAHA T.A., R.B. RENEAU, S. MOSTAGHIMI and D. LEE (1989). Vegetative filter strips for agricultural nonpoint source pollution control. Trans. ASAE, 32, 513-519. 
DOSSKEY M.G., K.D. HOAGLAND and J.R. BRANDLE (2007). Change in filter strip performance over ten years. J. Soil Water Conserv., 62, 21-32.

EDWARDS W.M. and L.B. OWENS (1991). Large storm effects on total soil loss. J. Soil Water Conserv., 46, 75-78.

GILLIAM J.W. (1994). Riparian wetlands and water quality. J. Environ. Qual., 23, 896-900.

HATFIELD J.L., D.D. JAYNES, M.R. BURKAT, C.A. CAMBARDELLA, T.B. MOORMAN, J.H. PRUEGER and M.A. SMITH (1999). Water quality in Walnut Creek Watershed: setting and farming practices. J. Environ. Qual., 28, 11-24.

ICE G. and D. BINKLY (2003). Forest streamwater concentrations of nitrogen and phosphorus. J. Forest., 101, 21-28.

JACOBS T.C. and J.W. GILLIAM (1985). Riparian losses of nitrate from agricultural waters. J. Environ. Qual., 14, 472-478.

JAYNES D.B., J.L. HATFIELD and D.W. MEEK (1999). Water quality in Walnut Creek watershed: herbicides and nitrate in surface waters. J. Environ. Qual., 28, 45-59.

JONES B.K., A.C. NEALE, M.S. NASH, R.D. WAN REMORTEL, J.D. WICKMAN, K.H. RITTERS and R.V. O’NEILL (2001). Predicting nutrient and sediment loads to streams from landscape matrics: a multiple watershed study from United States Mid-Atlantic Region. Landscape Ecol., 16, 301-312.

KANG S., H. LIN, W.J. GBUREK, G.L. FOLMAR and B. LOWERY (2008). Baseflow nitrate in relation to stream order and agricultural land use. J. Environ. Qual., 27, 808-816.

KELLY B.P. and M.L. POMES (1998). Preferential flow and transport of nitrate and bromide in claypan soil. Ground Water, 36, 484-494.

LAL R. (1976). Soil erosion problems on an Alfisol in Western Nigeria and their control. In: IITA Monogr., №1, IITA. Ibadan, Nigeria, 208 p.

LIAO N. and S. MARTEN (2000). Determination of total phosphorus by flow injection analysis colorimetry (acid perusulfate digestion method) 10-115-01-1-F. Zellweger Analytics, Milwaukee, WI, USA.

LOWRANCE R.R., L.S. ALTIER, D. NEWBOLD, R.R. SCHNABEL, P.M. GROFFMAN, J.M. DENVER,
D.L. CORRELL, W. GILLIAM, J.L. ROBINSON,

R.B. BRINSFIELD, K.W. STAVER, W. LUCAS and A.H. TODD (1997). Water quality functions of riparian forest buffers in Chesapeake Bay Watersheds. Environ. Manage., 21, 687-712.

LOWRANCE R.R., R. TODD, J. JR. FAIL, O. JR. HENDRICKSON, R. LEONARD and L. ASMUSSEN (1984). Riparian forests as nutrient filters in agriculture watersheds. BioSci., 34, 371-377.

LYONS J.B., J.H. GORRES and J.A. AMADOR (1998). Spatial temporal variability of phosphate retention in riparian forest soils. J. Environ. Qual., 27, 895-903.

MCINTYRE S.C. (1993). Reservoir sedimentation rates linked to long term changes in agricultural land use. Water Res. Bull., 29, 487-495.

MORGAN R.P.C., L. MARTIN and C.A. NOBLE (1987). Soil erosion in the United Kingdom: A case study from mid-Bedfordshire. Silsoe College Occasional Paper № 14, Silsoe College, Cranfield Univ., Silsoe, UK, 58 p.

MOTAVALLI P.P., S.H. ANDERSON and P. PENGTHAMKEERATI (2003). Surface compaction and poultry litter effects on corn growth, nitrogen availability, and physical properties of claypan soil. Field Crops Res., 84, 303-318.

NORD E.A. and L.E. LYON (2003). Managing material transfer and nutrient flow in an agricultural watershed. J. Environ. Qual., 32, 562-570.

OMERNIK J.M. and T.R. McDOWELL (1977). Nonpoint source-stream nutrient level relationships - A nationwide study. EPA-600/3-P77-105, Springfield, VA, U.S. Environmental Protection Agency.

OWENBY J.R. and D.S. EZELL (1992). Monthly station normals of temperature, precipitation, and heating and cooling degree days 1961-90. National Oceanic and Atmospheric Administration, National Climatic Data Center, Asheville, NC, USA.

PARSONS J.E., R.B. DANIELS, J.W. GILLIAM, T.A. DILLAHA (1994). Reduction in sediment and chemical load agricultural field runoff by vegetative filter strips. Report No. 286. Raleigh, NC, North Carolina Water Resources Institute, Chapel Hill, NC, USA, 75 p.

PERKINS B.D., K. LOHMAN, E.V. NIEUWENHUYSE and J.R. JONES (1998). An examination of land cover and stream water quality among physiographis provinces 
of Missouri, USA. Verh. Internat. Verein. Limnol., 26, 940-947.

PETERJOHN W.T. and D.L. CORRELL (1984). Nutrient dynamics in an agricultural watershed: observation on the role of riparian forest. Ecology, 65, 1466-1475.

PETERSON A. and B. VONDRACEK (2006). Water quality in relation to vegetative buffers around sinkholes in karst terrain. J. Soil Water Conserv., 61, 380-390.

PRITZLAFF D. (1999a). Determination of nitrate/nitrite in surface and wastewaters by flow injection analysis 10-107-04-1-C. Zellweger Analytics, Milwaukee, WI, USA.

PRITZLAFF D. (1999b). Determination of nitrate/nitrite in surface and wastewaters by flow injection analysis 10-107-04-1-B. Zellweger Analytics, Milwaukee, WI, USA.

PUCKETT L.J. (2004). Hydrogeologic control on the transport and fate of nitrate in ground water beneath riparian zones: results from thirteen studies across the United States. Water Sci. Technol., 49, 47-53.

ROBINSON C.A., M. GHAFFARZADEH and R.M. CRUSE (1996). Vegetative filter strip effects on sediment concentration in cropland runoff. J. Soil Water Conserv., 50, 227-230.

SAS INSTITUTE (1999). SAS user's guide. Statistics. SAS Inst., Cary, NC, USA.

SCHILLING K.E. and J. SPOONER (2006). Effects of watershed-scale land use change on stream nitrate concentration. J. Environ. Qual., 35, 2132-2145.

SCHMITT S.J. (1999). Application of a flow source mixing model and remote sensing to the hydrology and water quality of two small watersheds in Northern Missouri. M.S. Thesis, University of Missouri, Columbia, MO, USA, 214 p.

SCHMITT T.J., M.G. DOSSKEY and K.D. HOAGLAND (1999). Filter strip performance and processes for different vegetation, widths, and contaminants. J. Environ. Qual., 28, 1479-1489.

SEOBI T., S.H. ANDERSON, R.P. UDAWATTA and C.J. GANTZER (2005). Influence of grass and agroforestry buffer strips on soil hydraulic properties for an Albaqualf. Soil Sci. Soc. Am. J., 69, 893-901.
TOMER M.D. and M.R. BURKART (2003). Long-term effects of nitrogen fertilizer use on ground water nitrate in two small watersheds. J. Environ. Qual., 32, 2158-2171.

UDAWATTA R.P., P.P. MOTAVALLI, H.E. GARRETT and J.J. KRSTANSKY (2006a). Nitrogen loss in runoff from three adjacent agricultural watersheds with claypan soils. Agr. Ecosyst. Environ., 117, 39-48.

UDAWATTA R.P., G.S. HENDERSON, J.R. JONES and R.D. HAMMER (2006b). Runoff and sediment from row-crop, row-crop with grass strips, pasture, and forest watersheds. J. Water Sci., 19, 137-149.

UDAWATTA R.P., P.P. MOTAVALLI and H.E. GARRETT (2004). Phosphorus loss and runoff characteristics in three adjacent agricultural watersheds with claypan soils. J. Environ. Qual., 33, 1709-1719.

UDAWATTA R.P., J.J. KRSTANSKY, G.S. HENDERSON, and H.E. GARRETT (2002). Agroforestry practices, runoff, and nutrient loss: a paired watershed comparison. J. Environ. Qual., 31, 1214-1225.

UNITED STATES NATURAL RESOURCES CONSERVATION SERVICE (2006). Land resource regions and major land resource areas of the United States, the Caribbean and the Pacific Basin. Agriculture Handbook 296. USDA-NRCS, Govt. Printing Office, Washington, DC, USA.

WANG F., C.W. FRAISSE, N.R. KITCHEN and K.A. SUDDUTH (2003). Site-specific evaluation of the CROPGRO-soybean model on Missouri claypan soils. Agr. Syst., 76, 985-1005.

WELSCH D.J. (1992). Riparian forest buffers: Function and design for protection and enhancement of water resources. NA-PR-07-91.USDA Forest Service, Forest Resources Management, Randor, PA, USA, 20 p.

WIGINGTON P.J., S.M. GRIFFITH, J.A. FIELD, J.E. BAHAM, W.R. HOWARTH, J. OWEN, J.H. DAVIS, S.C. RAIN and J.J. STEINER (2003). Nitrate removal effectiveness of a riparian buffer along a small agricultural stream in Western Oregon. J. Environ. Qual., 32, 162-170.

ZHENG F., C. HUANG and D. NORTON (2004). Effects of near surface hydraulic gradients on nitrate and phosphorus losses in surface runoff. J. Environ. Qual., 33, 2174-2182. 